\title{
PROSEDUR PEMBERIAN PEMBIAYAAN MURABAHAH PADA BAITUL MAL WAT TAMWIL (BMT) TAQWA MUHAMMADIYAH PADANG
}

\author{
Aulia Suryani, Afriyeni \\ Akademi Keuangan dan Perbankan Padang \\ Afriyeni.yen@gmail.com
}

\begin{abstract}
ABSTRAK
Adapun tujuan dari penulisan penelitian ini adalah untuk memahami dan mengetahui bagaimana prosedur dalam pelaksanaan pembiayaan murabahah pada BMT Taqwa Muhammadiyah. Dalam menganalisa data, penulis menggunakan metode analisa data kualitatif sebagai metode penelitian yang menjelaskan secara deskriptif mengenai prosedur pemberian pembiayaan pada BMT Taqwa Muhammadiyah Padang. Hasil Penelitian Prosedur Pemberian Pembiayaan Murabahah BMT Taqwa Muhammadiyah Padang yaitu terlebih dahulu calon nasabah mengisi formulir permohonan pembiayaan, kemudian diperiksa kelengkapan administrasi calon nasabah oleh Administrasi Pembiayaan, setelah itu maka dilakukan survei oleh Kepala Cabang dengan Kepala Pembiayaan atau Kepala Pembiayaan dengan Account Officer, kemudian data-data yang di dapat dari hasil survei di analisa oleh Kepala Pembiayaan, setelah dilakukan analisa maka diambilah keputusan diterima atau ditolaknya permintaan pembiayaan, bila permintaan calon nasabah dianggap layak maka dikeluarkan Surat Persetujuan Pasilitas Pembiayaan (SP3), jika calon nasabah sepakat dengan SP3 maka dilakukan penandatanganan aqad pembiayaan, setelah itu maka nasabah bisa mengambil dana yang dibutuhkan.
\end{abstract}

Kata Kunci: Prosedur Pemberian Pembiayaan Murabahah

\section{LATAR BELAKANG}

Fenomena penerapan prinsip syariah dalam lembaga keuangan semakin berkembang pesat, tidak hanya di perbankan tetapi juga lembaga keuangan bukan bank (LKBB). Di sektor lembaga keuangan bank di kenal perbankan syariah, sedangkan pada lembaga keuangan bukan bank terdiri dari lembaga keuangan mikro syariah, asuransi syariah, obligasi syariah, pembiayaan syariah, pegadaian syariah, bisnis syariah dan lain-lain.

Ketika puluhan bank konvensional dilikuidasi akibat badai krisis ekonomi dan moneter yang menimpa bangsa Indonesia dan pasca lengsernya pemerintahan Orde Baru, Bank Muamalat Indonesia (BMI) menjadi pelopor perbankan yang tetap kukuh beroperasi sesuai syariah. Bank Muamalat Indonesia yang berdiri pada tahun 1991 diprakarsai oleh Majelis Ulama Indonesia (MUI) yang kemudian didukung sepenuhnya oleh Ikatan Cendikiawan Muslim Indonesia (ICMI) dan beberapa pengusaha muslim. 
Kompetisi dunia perbankan di Indonesia semakin semarak terhitung sejak hadirnya bank syariah yang dipelopori BMI tersebut. Orang pun mulai melirik lembaga-lembaga keuangan alternatif yang berdasarkan prinsip syariah. Banyak kalangan kemudian mencoba melihat dari dekat dan mencoba mempelajari sistem yang diterapkannya. Sebagai hasilnya lahirlah kemudian Bank Syariah Mandiri, Bank Negara Indonesia Syariah, dan seterusnya. Demikian juga dalam waktu relatif singkat ribuan Baitul Maal wat Tamwil (BMT) lainnya diberbagai penjuru tanah air.

Lahirnya lembaga keuangan syariah “ Baitul Maal wat Tamwil” yang biasa disebut BMT, sesungguhnya dilatarbelakangi oleh pelarangan riba (bunga) secara tegas dalam Al-Qur'an. Sebagian Ulama menganggap riba sebagai satu unsur buruk yang merusak masyarakat secara ekonomi, sosial maupun moral. Oleh karena itu, Al-Qur'an melarang umat Islam memberi atau memakan riba, seperti yang termaktup dalam surah Al-Baqarah ayat 275 yang artinya : "Allah menghalalkan jual beli dan mengharamkan riba". Kemudian di surah Ar-rum ayat 39 juga dijelaskan bahwa : "Sesuatu riba atau (kelebihan) yang kamu berikan agar ia menambah kelebihan pada harta manusia maka riba itu tidak menambah pada sisi Allah".

Baitul Maal Watamwil(BMT) memberi titik terang bagi usaha menengah dan mikro. BMT merupakan lembaga keuangan non-bank yang beroperasi dengan sistem syariah. Ciri khas dari BMT adalah memadukan antara layanan sosial dengan layanan komersial serta menerapkan sistem bagi hasil yang sangat sesuai dengan kebutuhan para pelaku usaha mikro kecil.

Dalam siklus ekonomi Islam, BMT dapat pula dikatagorikan koperasi syariah yakni lembaga ekonomi yang berfungsi untuk menarik, mengelola dan menyalurkan dana dari oleh dan untuk masyarakat. Selain merupakan lembaga pengelola dana masyarakat yang memberikan pelayanan tabungan, pinjaman pembiayaan, BMT juga mengelola dana sosial. Semua produk pelayanan dan jasa BMT dilakukan menurut ketentuan syariah yakni bagi hasil. (Hendi Suhendi, 2004:29)

Dalam melaksanakan kegiatannya, BMT mempunyai azaz, landasan, visi, misi, fungsi dan prinsip-prinsip serta ciri khas yang dimilki oleh BMT sebagai lembaga keungan syariah non-bank yang mempunyai legalitas dan badan hukum. BMT didirikan secara berproses dan bertahap yang dimulai dari Kelompok Swadaya Masyarakat (KSM) (Rudoni, 2008:60).

Sasaran utama kegiatan BMT adalah pada kegiatan usaha produktif dan investasi, dengan memadukan fungsi Baitul Maal dan Baitul Tamwil. Baitul Maal adalah lembaga yang mengarah pada usaha-usaha pengumpulan dan penyaluran dana yang non profit, yang fungsinya sebagai mediator antara penyaluran zakat, infak dan shadaqoh dengan para mustahik. Baitul Tamwil adalah lembaga komersil yang berfungsi sebagai mediator antara masyarakat yang memiliki kelebihan dana dengan masyarakat yang memiliki kekurangan dana untuk usaha yang produktif (Rudoni, 2008:60).

BMT dalam operasional usahanya pada dasarnya hampir mirip dengan perbankan yaitu melakukan kegiatan penghimpunan dana dari masyarakat dalam bentuk simpanan dan menyalurkan dana kepada masyarakat yang membutuhkan 
dalam bentuk pembiayaan, serta memberikan jasa-jasa yang dibutuhkan oleh masyarakat. Sistem yang digunakan BMT adalah "sistem Syari'ah". BMT Berorientasi bisnis, mencari keuntungan bersama, namun tetap berdasarkan "Syariah Islam" dalam meningkatkan ekonomi menengah kebawah, dan juga diperuntukkan masyarakat lingkungan sekitarnya, dengan kata lain BMT merupakan usaha milik bersama untuk masyarakat kecil. BMT dapat pula didirikan dalam Koperasi. BMT memiliki manajemen yang rapi, tertata administrasi dan pembukuannya memakai program komputer yang dikerjakan oleh pegawai yang profesional berpendidikan minimal S1. BMT bukan lembaga sosial, namun bergerak juga di bidang sosial seperti : menerima dan atau menyalurkan Zakat, Infaq dan shodaqah. dan juga mengadakan pengajian rutin dan pembinaan secara berkala yang waktu dan tempatnya ditentukan.

Usaha yang di jalankan BMT Taqwa Muhammadiyah adalah menyediakan pembiayaan bagi nasabah berdasarkan prinsip jual beli sesuai dengan ketentuan yang ditetapkan dalam peraturan pemerintah. Prinsip syariah dalam BMT diberlakukan untuk pendanaan maupun pembiayaan. Pembiayaan yang paling banyak disalurkan di BMT adalah pembiayaan berbasis jual beli dengan akad murabahah. Hal ini dikarenakan akad murabahah merupakan akad jual beli yang cukup mudah untuk diaplikasikan dalam penyaluran pembiayaan saat ini.

Pembiayaan Murabahah dalam istilah fiqh ialah akad jual beli atas barang tertentu dalam transaksi jual beli tersebut,penjual menyebutkan dengan jelas barang yang diperjual belikan termaksud harga pembelian dan keuntungan yang diambil. Murabahah dalam teknis perbankan adalah akad jual beli antara bank selaku penyedia dana dengan nasabah yang memesan untuk membeli barang. Salah satu akad yang digunakan BMT dalam transaksi pembiayaan berbasis jual beli adalah murabahah. Murabahah adalah kontrak jual-beli di mana bank bertindak sebagai penjual sementara nasabah sebagai pembeli. Harga jual adalah harga beli bank ditambah keuntungan. Walaupun akad murabahah ini sering digunakan, namun sebagian masyarakat belum mengerti tentang pelaksanaan akad ini. Sehingga banyak anggapan bahwa praktik pada lembaga keuangan syari'ah tidak berbeda jauh dengan lembaga keuangan konvensional yang terlebih dahulu dikenal oleh masyarakat luas.

BMT Taqwa Muhammadiyah merupakan lembaga keuangan mikro syariah yang melaksanakan fungsi intermediasi keuangan (financial intermediary function) yaitu menghimpun dan menyalurkan dana kepada masyarakat yang membutuhkan. BMT melayani sektor mikro, sehingga lembaga keuangan ini mampu melayani kebutuhan keuangan masyarakat ekonomi bawah yang sulit mengakses pembiayaan ke perbankan. Dalam kegiatan menyalurkan dananya dalam bentuk pembiayaan, BMT Taqwa Muhammadiyah, Padang menggunakan akad bagi hasil yaitu mudharabah dan murabahah untuk akad jual beli. Pembiayaan yang paling banyak disalurkan adalah pembiayaan berbasis jual beli dengan akad murabahah. Hal ini dikarenakan akad murabahah merupakan akad jual beli yang cukup mudah untuk diaplikasikan dalam penyaluran pembiayaan saat ini.

Beberapa ketentuan harus dipenuhi dalam melaksanakan akad murabahah agar transaksi akad tersebut terhindar dari riba dan sesuai dengan syariah. Salah 
satunya adalah syarat barang yang diakadkan dalam hal ini adalah barang yang dijual belikan. Menurut Fatwa Dewan Syariah Nasional MUI No. 04/DSNMUI/IV/2000 tentang murabahah disebutkan bahwa bank (BMT) harus membeli terlebih dahulu aset yang dipesan oleh nasabah secara sah dan kemudian menawarkan aset tersebut kepada nasabah. Syarat-syarat benda yang menjadi objek akad dalam akad murabahah, barang yang diperjualbelikan secara prinsip harus sudah menjadi milik bank (BMT). Tidak sah menjual barang-barang yang baru akan menjadi miliknya.

Sebelum nasabah memperoleh pembiayaan terlebih dahulu harus melalui beberapa tahapan penilaian mulai dari pengajuan proposal pembiayaan dan dokumen-dokumen yang diperlukan, pemeriksaan keaslian dokumen, analisis pembiayaa sampai dengan pembiayaan dikucurkan. Tahapan-tahapan dalam memberikan pembiayaan ini kita kenal prosedur pemberian pembiayaan murabahah. Tujuan prosedur pemberian pembiayaan murabahah adalah untuk memastikan kelayakan suatu pembiayaan, diterima atau ditolak. Dalam menentukan kelayakan suatu pembiayaan maka dalam setiap tahap selalu dilakukan penilaian yang mendalam. Apabila dalam penilaian mungkin ada kekurangan maka pihak BMT dapat meminta kembali ke nasabah atau bahkan langsung ditolak.

Berdasarkan uraian dari penjelasan diatas penulis bermaksud membandingkan antara teori dan praktek dalam bentuk tugas akhir dengan judul "Prosedur Pemberian Pembiayaan Murabahah Pada BMT Taqwa Muhammadiyah, Padang".

Adapun perumusan masalah dalam penulisan tugas akhir ini yaitu "bagaimana prosedur pemberian pembiayaan murabahah pada BMT Taqwa Muhammadiyah Padang".

\section{METODE PENELITIAN}

Dalam pengumpulan data dan bahan untuk melakukan penelitian ini digunakan metode penelitian, sebagai berikut :

\section{Metode pengumpulan data}

a. Studi Lapangan (Field Research)

Peninjauan langsung ke objek penelitian yang dipilih untuk meneliti hasil data primer. Penelitian langsung ke lapangan ini akan dapat membantu penulis untuk melengkapi data yang diperlukan. Adapun cara riset lapangan ini adalah dengan mewawancarai langsung pihak-pihak yang berkepentingan dalam hal ini adalah perusahaan atau instansi yang terkait.

b. Studi Perpustakaan. (Library Research)

Penelitian yang dilakukan ke perpustakaan berupa buku-buku ilmiah dan tulisan-tulisan yang berhubungan dengan pembahasan yang dilakukan.

\section{Metode Analisa Data}

Dalam menganalisa data, penulis menggunakan metode analisa data kualitatif sebagai metode penelitian yang menjelaskan secara deskriptif mengenai prosedur pemberian pembiayaan pada BMT Taqwa Muhammadiyah Padang. Metode analisa ditinjau dari dua segi yang berbeda yaitu antara teori dan praktek yang perlu dipertemukan sehingga 
dapat diketahui sejauh mana pelaksanaanya, apakah perbedaan yang timbul menyangkut prinsip dasar konsep itu sendiri. Dengan menganalisa perbandingan, pertanyaan itu akan terjawab selanjutnya dan hasil analisa itu dipergunakan sebagai dasar pengambilan kesimpulan dan saran.

\section{TINJAUAN PUSTAKA}

\section{Pengertian Baitul Maal wat Tamwil (BMT).}

Baitul Maal wat Tamwil (BMT) adalah lembaga pendukung kegiatan ekonomi pengusaha mikro (sangat kecil) dan pengusaha kecil kebawah bedasarkan sistem syariah.

Menurut Ridwan (2004), BMT merupakan sebuah lembaga yang tidak saja berorientasi bisnis tetapi juga sosial, dan juga lembaga yang tidak melakukan pemusatan kekayaan pada sebagian kecil orang tetapi lembaga yang kekayaannya terdistribusi secara merata dan adil. BMT juga merupakan lembaga keuangan syariah yang jumlahnya paling banyak dibandingkan lembaga - lembaga keuangan syariah lainnya. Menurut Aziz (2004), pada tahun 2001 jumlah BMT yang terdaftar sebanyak 2938, sedangkan Pusat Inkubasi Bisnis dan Usaha Kecil (PINBUK) menargetkan terdapat 10.000 BMT di akhir tahun 2010.

Pinbuk SOM (2008) menyatakan bahwa BMT merupakan salah satu bentuk dari lembaga keuangan mikro bukan bank yang beroperasi berdasarkan prinsip - prinsip syariah Islam (untuk selanjutnya disebut Syariah). Lembaga keuangan berfungsi sebagai lembaga intermediasi antara pihak yang memiliki kelebihan dana (investor) dengan pihak yang memerlukan dana (pelaku usaha).

BMT adalah ringkasan dari nama Baitul Maal wat Tamwil. Istilah Baitul Maal wat Tamwil berasal dari khasanah peradaban Islam yang terdiri dari baitul maal dan baitul tamwil. Secara etimologis pengertian baitul maal adalah rumah harta (sosial), sedangkan baitul tamwil adalah rumah niaga / pengembangan harta. Pada dasarnya kegiatan Baitul Maal Wa Tamwil terdiri atas dua lembaga yaitu:

1. Baitul Maal.

Baitul Maal merupakan lembaga keuangan yang berorientasi social keagamaan yang usaha utamanya menampung serta menyalurkan harta masyarakat berupa Zakat, Infaq, Shadaqah (ZIS) berdasarkan ketentuan yang telah ditetapkan Al-Qur'an dan Sunah Rasul.

Ciri - ciri operasional Baitul Maal :

1) Visi dan misi social.

2) Non - profit (nirlaba).

3) Memiliki fungsi sebagai mediator antara pemberi zakat (muzakki) dan penerima zakat (mustahik).

4) Tidak diperbolehkan mengambil profit apapun dalam operasionalnya.

2. Baitul Tamwil.

Baitul Tamwil merupakan lembaga keuangan yang kegiatan utamanya menghimpun dana masyarakat dalam bentuk tabungan ataupun deposito dan menyalurkannya kembali kepada masyarakat dalam bentuk pembiayaan berdasarkan prinsip syariah melalui mekanisme yang lazim dalam dunia perbankan.

Ciri - ciri operasional baitul tamwil 
1) Visi dan misi ekonomi kerakyatan.

2) Profit oriented / berorientasi laba.

3) Dijalankan sesuai dengan prinsip Syariah.

4) Memiliki peran mediator / lembaga intermediasi antara pemilik kelebihan dana dan pihak yang memerlukan dana.

Tujuan pembentukan BMT adalah untuk memperbanyak jumlah BMT, sedangkan tujuan BMT itu sendiri adalah untuk :

a. Memajukan kesehatan anggota dan masyarakat umum.

b. Meningkatkan kekuatan dan posisi tawar pengusaha kecil dengan pelaku lain.

Hal-hal yang perlu diperhatikan dalam pembentukan BMT adalah:

1) Motivator (penggerak), memiliki peranan yang sangat signifikan terhadap sukses awal pendirian BMT. Penggerak ini berasal dari masyarakat setempat yang atas inisiatif sendiri atau inisiatif PINBUK dan pihak lain berminat membentuk BMT.

2) Pendekatan pada tokoh kunci yang dapat terdiri dari pimpinan formal, pimpinan informal, usahawan, hartawan, dan dermawan. Para tokoh ini diharapkan bersedia menjadi panitia pembentukan BMT.

3) Pendekatan pada para calon pendiri. Pendiri minimal 20 orang yang terdiri dari tokoh-tokoh yang mewakili berbagai kalangan masyarakat seperti pimpinan formal, agama, adat, pengusaha dan masyarakat banyak. Badan pendiri mengadakan rapat dan menetapkan Anggaran Dasar dan Anggaran Rumah Tangga BMT serta memilih pengurus yang terdiri dari 3-5 orang.

4) Pengurus mengadakan seleksi pengelola yang jumlahnya minimal 3 orang yang terdiri dari Manager, Bagian Pembiayaan, Bagian Administrasi atau Keuangan dan bagian-bagian lain yang dibutuhkan.

5) Para pengelola yang ditunjuk segera memasyarakatkan BMT dan mencari anggota dan BMT mulai beroperasi.

6) Antara pengurus dan pengelola tidak mempunyai hubungan kekeluargaan.

7) Organisasi yang dapat membentuk BMT antara lain seluruh anggota masyarakat, kelompok-kelompok masyarakat, organisasi sosial, organisasi profesi, LSM, dan proyek-proyek pemberdayaan masyarakat.

8) Kelompok yang dapat dikembangkan menjadi BMT antara lain : arisan, simpan pinjam, pengajian, tani, usaha ekonomi produktif dan lain-lain.

Baitul Maal wat Tamwil (BMT) adalah kelompok swadaya masyarakat sebagai Lembaga Ekonomi rakyat yang berupaya mengembangkan usaha-usaha produktif dan investasi dengan sistem bagi hasil untuk meningkatkan kualitas ekonomi pengusaha kecil kebawah dalam upaya pengentasan kemiskinan. BMT adalah lembaga keuangan mikro syari'ah formal yang dapat dengan mudah diakses oleh masyarakat berpendapatan rendah. BMT memiliki ciri-ciri utama sebagai berikut:

1. Berorientasi bisnis, mencari laba bersama, meningkatkan pemanfaatan ekonomi paling banyak untuk anggota dan lingkungannya.

2. Bukan lembaga sosial tetapi dapat dimanfaatkan untuk mengefektifkan penggunaan zakat, infak, dan sedekah bagi kesejahteraan orang banyak. 
3. Ditumbuhkan dari bawah berlandaskan peran serta masyarakat disekitarnya.

4. Milik bersama masyarakat kecil bawah dan kecil dari lingkungan BMT itu sendiri, bukan milik orang seorang atau orang dari luar masyarakat itu.

\section{Fungsi dan Peranan BMT}

Fungsi dan peranan BMT Taqwa Muhammadiyah adalah sebagai penyedia dan pengelola jasa keuangan. Kegiatan jasa keuangan yang dikembangkan oleh BMT Taqwa Muhammadiyah adalah penghimpunan dana dan menyalurkannya melalui kegiatan pembiayaan dari anggota dan untuk anggota atau non anggota. Kegiatan ini dapat disamakan secara operasioal dari kegiatan simpan pinjam dalam koperasi atau kegiatan perbankan secara umum. Karena BMT Taqwa Muhammadiyah merupakan lembaga keuangan syariah maka dasar kegiatannya adalah sama dengan sistem perbankan syariah. Hal ini juga terlihat dari jenis produk dan jasa yang sama dengan yang ada dalam perbankan syariah.

\section{Prinsip Utama BMT}

Dalam melaksanakan usahanya BMT, berpegang teguh pada prinsip utama sebagai berikut:

a. Keimanan dan ketaqwaan kepada Allah SWT dengan menerapkan prinsip-prinsip Syari'ah dan muamalah Islam ke dalam kehidupan nyata.

b. Keterpaduan, yakni nilai-nilai sepiritual dan moral menggerakkan dan mengarahkan etika bisnis yang dinamis, produktif, progresif adil dan berakhlaq mulia.

c. Kekeluargaan, yakni mengutamakan kepentingan bersama di atas kepentingan pribadi. Semua pengelola pada setiap tingkatan, pengurus dengan semua lininya serta anggota, dibangun rasa kekeluargaan, sehingga akan tumbuh rasa saling melindungi dan menanggung.

d. Kebersamaan, yakni kesatuan pola pikir, sikap dan cita-cita antara semua elemen BMT. Antara pengelola denga pengurus harus memiliki satu visi dan bersama-sama anggota untuk memperbaiki kondisi ekonomi dan sosial.

e. Kemandirian, yakni mandiri di atas semua golongan politik. Mandiri berarti juga tidak tergantung dengan dana-dana pinjaman dan 'bantuan' tetapi senantiasa produktif untuk menggalang dana masyarakat sebanyakbanyaknya.

f. Profesionalisme, yakni semangat kerja yang tinggi dan dilandasi dengan dasar keimanan. Kerja yang tidak hanya berorientasi pada kehidupan dunia saja, tetapi juga kenikmatan dan kepuasan rohani dan akhirat. Kerja keras dan cerdas yang dilandasi denga bekal pengetahuan (knowladge) yang cukup, ketrampilan yang terus ditingkatkan (skill) serta niat ghirah yang kuat (Attitude). Semua itu dikenal dengan kecerdasan emosional, spritual dan intelektual. Sikap profesionalisme dibangun dengan semangat untuk terus belajar demi mencapai tingkat standar kerja yang tinggi.

g. Istiqomah, konsisten, konsekuen, kontinuitas/berkelanjutan tanpa henti dan tanpa pernah putus asa. Setelah mencapai suatu tahap, maka maju lagi ke tahap berikutnya dan hanya kepada Allah SWT kita berharap. 


\section{Keunggulan dan Kelemahan antara BMT dengan Perbankan Konvensional.}

BMT sebagai alternatif Bank-bank konvensional, memiliki keunggulankeunggulan yang juga merupakan perbedaan dan perbandingan jika dengan perbankan konvensional. Disamping hal tersebut muncul juga kelemahankelemahan karena sebagai pemain baru dalam dunia lembaga keuangan.

\section{a) Keunggulan BMT adalah:}

1. BMT memiliki dasar hukum operasional yakni Al Qur'an dan Al Hadist. Sehingga dalam operasionalnya sesuai dengan prinsip-prinsip dasar seperti diperintahkan oleh Allah SWT, juga nilai dasar seperti yang dicontohkan Rasulullah SAW.

2. BMT mendasarkan semua produk dan operasinya pada prinsip-prinsip efisiensi, keadilan, dan kebersamaan.

3. Adanya kesamaan ikatan emosional keagamaan yang kuat antara pemegang saham, pengelola, dan nasabah, sehingga dapat dikembangkan kebersamaan dalam menghadapi resiko usaha dan membagi keuntungan secara jujur dan adil.

4. Adanya keterikatan secara religi, maka semua pihak yang terlibat dalam BMT akan berusaha sebaik-baiknya sebagai pengalaman ajaran agamanya sehingga berapa pun hasil yang diperoleh diyakini membawa berkah.

5. Adanya fasilitas pembiayaan (Al Mudharabah dan Al Musyarakah) yang tidak membebani nasabah sejak awal dengan kewajiban membayar biaya secara tetap, hal ini memberikan kelonggaran pisikologis yang diperlukan nasabah untuk dapat berusaha secara tenang dan bersungguh-sungguh.

6. Adanya fasilitas pembiayaan (Al Murabahah dan Al Ba'i Bitsaman Ajil) yang lebih mengutamakan kelayakan usaha dari pada jaminan (kolateral) sehingga siapa pun baik pengusaha ataupun bukan mempunyai jaminan kesempatan yang luas untuk berusaha.

7. Tersedia pembiayaan (Qardu Hasan) yang tidak membebani nasabah dengan biaya apapun, kecuali biaya yang dipergunakan sendiri : seperti bea materai, biaya notaris, dan sebagainya. Dana fasilitas ini diperoleh dari pengumpulan zakat, infak dan sadaqah, para amil zakat yang masih mengendap.

8. Dengan diterapkannya sistem bagi hasil sebagai pengganti bunga, maka tidak ada diskriminasi terhadap nasabah yang didasarkan atas kemampuan ekonominya.

9. Dengan adanya sistem bagi hasil, maka untuk kesehatan BMT yang bisa diketahui dari naik turunnya jumlah bagi hasil yang diterima.

10. Dengan diterapkannya sistem bagi hasil, maka persaingan antar BMT berlaku wajar yang diperuntukkan oleh keberhasilan dalam membina nasabah dengan profesionalisme dan pelayanan yang baik.

b) Kelemahan-kelemahan serta permasalahan-permasalahan yang ada dalam BMT Islam (Warkum Sumitro, 1996) adalah:

1. Dalam operasional BMT, pihak-pihak yang terlibat didasarkan pada ikatan emosional keagamaan yang sama, sehingga antara pihak-pihak khususnya pengelola BMT dan BMT harus saling percaya, bahwa mereka sama-sama beritikad baik dan jujur dalam bekerjasama. BMT dengan sistem ini terlalu 
berprasangka baik kepada semua nasabah dan berasumsi bahwa semua orang yang terlibat adalah jujur. Dengan demikian, BMT rawan terhadap mereka yang beritikad tidak baik sehingga diperlukan usaha tambahan untuk mengawasi nasabah yang menerima pembiayaan dari BMT karena tidak dikenal bunga, denda keterlambatan dan sebagainya.

2. Sistem bagi hasil yang adil memerlukan tingkat profesionalisme yang tinggi bagi pengelola BMT untuk membuat penghitungan yang cermat dan terus-menerus.

3. Motivasi masyarakat muslim untuk terlibat dalam aktivitas BMT adalah emosi keagamaan, ini berarti tingkat efektifitas keterlibatan masyarakat muslim dalam BMT tergantung pada pola pikir dan sikap masyarakat itu sendiri.

4. Semakin banyak umat Islam memanfaatkan fasilitas yang disediakn BMT, sementara belum tersedia proyek-proyek yang bisa di biayai sebagai akibat kurangnya tenaga-tenaga profesional yang siap pakai, maka BMT akan menghadapi "kelebihan likuiditas".

5. Salah satu misi BMT yakni mengentaskan kemiskinan yang sebagian besar kantong-kantong kemiskinan terdapat di pedesaan.

\section{c) Perbedaan Sistem Bagi Hasil dengan Sistem Bunga.}

Menurut kamus, bunga adalah uang balas jasa atau ganti rugi yang diberikan kepada orang yang telah meminjamkan uang atau modal (Poerwadarmita, 1991:165).

Menurut Sumitro, 1996:12 dalam pengertian lain adalah: "Bunga adalah biaya yang dikenakan pada peminjam uang atau imbalan yang diberikan kepada penyimpan yang besarnya telah ditetapkan dimuka, biasanya ditentukan dalam bentuk persentase $(\%)$ dan terus dikenakan selama masih ada sisa simpanan atau pinjaman sehingga tidak hanya terbatas pada jangka waktu kontrak".

\section{Pembiayaan Murabahah}

Kegiatan utama sebuah bank adalah menghimpun dana dari masyarakat luas dalam bentuk simpanan giro, tabungan, dan deposito dan menyalurkan kembali dana tersebut kepada masyarakat yang membutuhkan dana. Pengalokasian tersebut dapat diwujudkan dalam bentuk pinjaman atau lebih dikenal dengan kredit atau pembiayaan. Pembiayaan bagi bank yang menjalankan prinsip syariah, bukan pembiayaan yang lazimnya dilakukan oleh lembaga keuangan non bank.

Menurut Antonio (2001, hal. 160) pembiayaan adalah pemberian fasilitas penyediaan dana untuk memenuhi kebutuhan pihak - pihak yang kekurangan dana. Menurut Kasmir (2001 : 92) pembiayaan adalah penyediaan uang atau tagihan yang dapat dipersamakan dengan itu, berdasarkan persetujuan atau kesepakatan antara bank dengan pihak lain yang mewajibkan pihak yang dibiayai untuk mengembalikan uang atau tagihan tersebut setelah jangka waktu tertentu dengan hasil bagi.

Berdasarkan beberapa pengertian di atas, maka dapat disimpulkan bahwa pembiayaan adalah penyediaan uang atau barang berdasarkan kesepakatan antara lembaga keuangan dan seseorang untuk memenuhi kebutuhannya dengan jangka waktu yang telah disepakati bersama. 
Menurut Djumhana (2000: 370) pembiayaan dalam arti luas mencakup unsur-unsur sebagai berikut :

a) Kepercayaan.

b) Kesepakatan.

c) Jangka waktu.

d) Resiko.

e) Balas jasa.

Berikut akan dijelaskan unsur pembiayaan satu persatu.

a) Kepercayaan.

Kepercayaan yaitu suatu keyakinan pemberi pembiayaan bahwa pembiayaan yang diberikan akan benar-benar diterima kembali dimasa yang akan datang.

b) Kesepakatan.

Kesepakatan yaitu perjanjian antara si pemberi pembiayaan yang telah disepakati dengan nasabah, dimana masing-masing pihak menandatangani hak dan kewajiban masing - masing.

c) Jangka waktu.

Jangka waktu mencakup masa pengembalian pembiayaan yang telah disepakati. Jangka waktu tersebut bisa berbentuk jangka pendek, jangka menengah dan jangka panjang.

d) Resiko.

Resiko merupakan tenggang waktu pengembalian tak tertagihnya pemberian pembiayaan. Semakin panjang suatu pembiayaan semakin besar resikonya. Demikian pula sebaliknya, resiko terbesar yang dipikul oleh bank berasal dari kegiatan pemberian pembiayaan.

e) Balas jasa.

Balas jasa ini merupakan keuntungan atas pemberian pembiayaan. Balas jasa bagi Bank Syariah ditentukan dengan bagi hasil.

\section{Tujuan Pembiayaan}

Tujuan pembiayaan menurut Muhammad (2005:17) dikelompokan menjadi dua tujuan pembiayaan terdiri dari:

1. Tujuan pembiayaan untuk tingkat makro.

2. Tujuan pembiayaan untuk tingkat mikro.

Adapun penjelasan dari kedua tujuan pembiayaan di atas diantaranya adalah sebagai berikut:

1. Tujuan pembiayaan untuk tingkat makro, pembiayaan bertujuan untuk:

a. Peningkatan ekonomi umat, artinya: masyarakat yang tidak dapat akses secara ekonomi, dengan adanya pembiayaan mereka dapat melakukan akses ekonomi, dengan demikian dapat meningkatkan taraf ekonominya.

b. Tersedianya dana bagi peningkatan usaha, artinya: untuk pengembangan usaha membutuhkn dana tambahan. Dana tambahan ini dapat diperoleh dengan melakukan aktivitas pembiayaan. Pihak yang surplus dana menyalurkan kepada pihak yang minus dana sehingga dapat terbantu.

c. Meningkatkan produktivitas, artinya: adanya pembiayaan memberikan peluang bagi usaha masyarakat sehingga mampu meningkatkan daya 
produksinya sebab upaya produksi tidak akan dapat berjalan tanpa adanya dana.

d. Membuka lapangan kerja baru, artinya: dengan dibukanya sektor-sektor usaha melalui penambahan dana pembiayaan, maka sektor usaha tersebut akan menyerap tenaga kerja. Hal ini berarti menambah atau membuka lapangan kerja baru.

2. Tujuan pembiayaan untuk tingkat mikro, pembiayaan bertujuan untuk:

a. Upaya memaksimalkan laba, artinya: setiap usaha yang memiliki tujuan tertinggi yaitu menghasilkan laba usaha, setiap pengusaha menginginkan atau mampu mencapai laba maksimal. Untuk dapat menghasilkan laba yang maksimal maka mereka perlu dukungan dana yang cukup.

b. Upaya meminimalkan resiko, artinya: usaha yang dilakukan mampu menghasilkan laba maksimum, maka pengusaha harus mampu meminimalkan resiko yang mungkin timbul. Resiko kekurangan modal usaha dapat diperoleh melalui tindakan pembiayaan.

c. Penyaluran kelebihan dana, artinya: dalam kehidupan masyarakat ini ada pihak yang memiliki kelebihan sementara ada pihak yang kekurangan. Dalam kaitannya dengan masalah dana, maka mekanisme pembiayaan dapat menjadi jembatan dalam penyeimbangan dan penyaluran kelebihan dana dari pihak yang kelebihan dana (surplus) kepada pihak yang kekurangan (minus) dana.

\section{Manfaat Pembiayaan}

Menurut Pinbuk, 2008, manfaat pembiayaan, yaitu :

1. Manfaat pembiayaan bagi anggota dan calon anggota adalah sebagai berikut :

a. Sebagai modal untuk membiayai usaha produktif .

b. Menambah modal kerja yang sudah berjalan sehingga dapat meningkatkan keuntungan.

c. Memperoleh sarana produksi untuk menunjang usaha.

d. Mendapatkan barang kebutuhan dengan cara pembayaran yang ringan.

2. Manfaat pembiayaan bagi BMT adalah sebagai berikut :

a. Merupakan sumber pembentukan kekayaan dan pendapatan.

b. Menjamin kelangsungan kegiatan usaha.

c. Mewujudkan kepedulian sosial: pembiayaan usaha mikro dan berfungsi sebagai ibadah dalam menanggulangi kemiskinan dan ketimpangan sosial.

\section{Prinsip pemberian pembiayaan.}

Menurut Pinbuk (2008: 69), dalam melakukan penilaian permohonan pembiayaan seorang marketing harus memperhatikan prinsip utama yang dikenal dengan $5 \mathrm{C}$ yang berkaitan dengan kondisi keseluruhan calon anggota.

Analisis pembiayaan dengan $5 \mathrm{C}$ adalah sebagai berikut :

1) Character, adalah penilaian terhadap sifat, kepribadian dan integritas calon anggota pembiayaan dengan tujuan untuk mengetahui kemauan dan komitmen untuk memenuhi kewajibannya.

2) Capacity, adalah penilaian secara obyektif tentang kemampuan anggota pembiayaan untuk melakukan pembayaran. Kemampuan diukur dengan catatan 
prestasi anggota di masa lalu dan didukung dengan pengamatan dilapangan atas sarana usahanya seperti toko, karyawan, alat-alat, pabrik serta metode kegiatan.

3) Capital, adalah penilaian terhadap kemampuan modal yang dimiliki oleh calon anggota yang diukur dengan posisi perusahaan secara keseluruhan yang ditujukan oleh rasio financial dan penekanan pada komposisi modalnya.

4) Collatertal, adalah jaminan yang dimiliki calon anggota. Penelitian ini bertujuan untuk lebih meyakinkan bahwa jika suatu resiko kegagalan pembayaran tercapai terjadi, maka jaminan dapat dipakai sebagai pengganti dari kewajiban.

5) Condition, BMT harus melihat kondisi ekonomi yang terjadi dimasyarakat secara spesifik melihat adanya keterkaitan dengan jenis usaha yang dilakukan oleh calon anggota. Hal tersebut karena kondisi eksternal berperan besar dalam proses berjalannya usaha calon anggota.

\section{Pengertian Murabahah}

Murabahah menurut Firdaus Furywardana (2008:21), menyatakan bahwa: "Murabahah adalah menjual barang dengan harga jual sebesar harga perolehan ditambah keuntungan yang disepakati dan penjual harus mengungkapkan harga perolehan barang tersebut kepada pembeli."

Murabahah menurut Ascarya (2007: 81) menyatakan bahwa: "Murabahah adalah istilah dalam fiqih islam yang berarti suatu bentuk jual beli tertentu ketika penjual menyatakan biaya perolehan barang, meliputi harga barang dan biaya biaya lain yang dikeluarkan untuk memperoleh barang tersebut dan tingkat keuntungan (margin) yang diinginkan.

Berdasarkan definisi diatas dapat disimpulkan bahwa murabahah merupakan akad jual beli yang harga jualnya ditambah keuntungan yang telah disepakati oleh kedua belah pihak.

\section{Pengertian Pembiayaan Murabahah}

Pembiayaan murabahah menurut Muhammad (2005:94), adalah sebagai berikut: "Pembiayaan Murabahah (dari kata ribhu= keuntungan); Bank sebagai penjual dan nasabah sebagai pembeli. Barang diserahkan segera dan pembayaran dilakukan secara tangguh."

Pembiayaan murabahah menurut Karim (2006:113), adalah sebagai berikut: "Pembiayaan murabahah adalah transaksi jual beli, yaitu pihak bank syari'ah bertindak sebagai penjual dan nasabah sebagai pembeli dengan harga jual dari bank adalah harga beli dari pemasok ditambah keuntungan dalam presentase tertentu bagi bank syari'ah sesuai kesepakatan."

Berdasarkan pengertian diatas dapat disimpulkan bahwa pembiayaan murabahah merupakan pembiayaan dengan sistem jual beli yang harga jualnya di tambah keuntungan dan pembayarannya dilakukan dengan tangguh.

\section{Rukun dan Syarat-syarat Pembiayaan Murabahah}

Cara pembayaran dan jangka waktu disepakati bersama, dapat secara tunai ataupun secara angsuran. Murabahah dengan pembayaran secara angsuran ini disebut dengan Bai' Bitsaman Ajil.

1. Rukun Murabahah.

a. Pihak yang berakad: penjual dan pembeli. 
b. Objek yang diakadkan: Barang yang diperjualbelikan dan harga.

c. Sighat/ Akad: Serah (Ijab) dan Terima (Qabul).

2. Syarat- syarat murabahah .

1) Pihak yang berakad:

a. Sebagai keabsahan suatu perjanjian (akad) para pihak harus cakap hukum.

b. Sukarela (ridho), tidak dalam keadaan terpaksa / dipaksa dan tidak di bawah tekanan.

2) Obyek yang diperjualbelikan:

a. Barang yang diperjualbelikan tidak termasuk barang yang dilarang (haram), dan bermanfaat serta tidak menyembunyikan adanya cacat barang.

b. Merupakan hak milik penuh pihak yang berakad.

c. Sesuai spesifikasinya antara yang diserahkan penjual dan yang diterima pembeli.

d. Penyerahan dari penjual ke pembeli dapat dilakukan.

3) Sighat / Akad :

a. Harus jelas dan disebutkan secara spesifik (siapa) para pihak yang berakad.

b. Antara ijab qabul (serah terima) harus selaras dan transparan baik dalam spesifikasi barang (penjelasan fisik barang) maupun harga yang disepakati (memberitahu biaya modal kepada pembeli).

c. Tidak mengundang klausul yang bersifat menggantungkan keabsahan transaksi pada kejadian yang akan datang.

d. Tidak dibatasi waktu, misalnya: "saya jual ini kepada anda untuk jangka waktu 12 bulan setelah itu jadi milik saya sendiri."

Mekanisme dan Prosedur Pembiayaan pada BMT Taqwa Muhammadiyah Padang

Ketentuan Umum Pembiayaan pada BMT Taqwa Muhammadiyah Padang

Pada prinsipnya produk pembiayaan di BMT Taqwa Muhammadiyah Padang adalah pembiayaan dengan aqad Murabahah dan Ba'i Bitsaman Ajil. Prinsip jual- beli dilaksanakan sehubungan dengan adanya perpindahan kepemilikan barang, dalam akad harga jual merupakan harga asal ditambah dengan keuntungan yang disepakati antara pihak BMT Taqwa Muhammadiyah Padang dengan nasabah. Pada perjanjian atau akad BMT Taqwa Muhammadiyah Padang untuk akad pembelian barangnya diwakilkan ke nasabah untuk membelinya, makaakadnya menjadi murabahah wal wakalah ( jual beli yang diwakilkan ) yang diberikan kepada nasabah adalah modal sesuai dengan harga barang, pada saat pengembaliannya baru modal ditambah dengan margin keungtungan.

Yang menjadi ketentuan umum untuk calon nasabah pembiayaan sebagai berikut:

a. Beragama Islam Dan Kewarganegaraan Indonesia. 
Hal ini mutlak karena BMT Taqwa Muhammadiyah Padang merupakan suatau lembaga keuangan islam yang bertujuan untuk memajukan kesejahteraan umat Islam di Indonesia.

b. Punya Usaha yang Layak dan milik sendiri.

Suatu usaha dinilai layak jika usaha tersebut berjalan 1 (satu) tahun, yang berlokasi strategis dengan Profit yang bagus atau paling tidak punya potensi untuk dapat dikembangkan dan usaha tersebut tidak usaha bersama.

c. Pelarangan Pembiayaan.

1. Pembiayaan tidak diberikan kepada perorangan atau badan usaha yang tidak berdomisili di Sumatera Barat.

2. Pembiayaan tidak diberikan kepada perorangan atau badan usaha yang tercatat dicatatan hitam (black lease).

3. Pembiayaan tidak diberikan kepada usaha yang haram dan yang bertentangan dengan syari'at Islam, seperti:
a. Klub malam.
b. Arena Perjudian.
c. Peternakan babi.
d. Kolam renang.
e. Bioskop.
f. Dan usaha lain yang dilarang dalam Syariat Islam.

\section{Prosedur Pemberian Pembiayaan Murabahah pada BMT Taqwa Muhammadiyah Padang.}

Dalam penyaluran pembiayaan ada beberapa aktivitas yang harus dilakukan sehubungan dengan pelaksanaan aktivitas tersebut, maka prosedur yang harus dijalani adalah:

\section{a. Mengisi Permohonan Pembiayaan.}

Calon nasabah mengisi formulir permohonan pembiayaan yang berisikan yang telah disediakan oleh BMT Taqwa Muhammadiyah dan boleh juga membuat permohonan sendiri yang berisikan tentang identitas nasabah, jenis usaha yang akan di biayai dan jenis anggunan, serta melampirkan :

1) Foto copy KTP Suami Istri.

2) Foto copy KK (Kartu Keluarga).

3) Foto copy rekening tabungan.

4) Surat Izin Usaha.

5) Gambaran umum usaha yang telah berjalan.

6) Rencana atau prospek usaha ke depan.

7) Perincian penggunaan dana.

8) Jumlah dan jangka waktu penggunaan dana.

9) Foto copy jaminan pembiayaan berupa ;

a) Foto copy sertifikat.

b) Foto copy BPKB dan disertai dengan pajak.

10) Surat persetujuan suami istri.

\section{b. Pemeriksaan Kelengkapan Administrasi.}

Formulir permohonan yang diajukan akan diperiksa oleh Administrasi Pembiayaan, untuk memeriksa apakah kelengkapan administrasi calon 
nasabah sudah lengkap. Apabila sudah lengkap maka bagian administrasi akan meneruskan ke Account Officer untuk dilakukan Survei.

\section{c. Pelaksanaan Survei.}

Setelah kelengkapan administrasi, biasanya survei dilakukan paling lama 2 hari setelah penyerahan kelengkapan administrasi. Survei ini biasanya akan dilaksanakan oleh Kepala Cabang dengan Kepala Pembiayaan atau Kepala Pembiayaan dengan Account Officer. Survei ini bertujuan untuk mendapatkan keterangan data nasabah meliputi:

1) Tempat usaha calon nasabah.

2) Rumah calon nasabah.

3) Agunan calon nasabah.

\section{d. Pembuatan Nota Analisa.}

Setelah survei dilakukan, maka data - data yang di dapat sebelum dan sesudah survei, maka kepala pembiayaan akan melakukan analisa terhadap kelayakan dari usaha calon nasabah. Biasanya analisa yang dilakukan adalah menggunakan $5 \mathrm{C}$ :

1) Character (karakter).

Merupakan sifat-sifat calon debitur seperti kejujuran, perilaku, dan ketaatannya. Gunanya untuk mendapatkan data-data mengenai karakter calon debitur tersebut, caranya dapat dilakukan melalui pengumpulan informasi dari referensi.

a. Dari tetangga tempat tinggal calon nasabah.

b. Tetangga tempat usaha.

c. Dari bank lain yang telah memberikan pembiayaan sebelum mengajukan pembiayaan BMT Taqwa Muhammadiyah Padang.

2) Capital (Modal).

Yang di analisa dalam permodalan ini yaitu tentang besar dan struktur modal termasuk kinerja dari modal itu sendiri. BMT Taqwa Muhammadiyah Padang mensyaratkan bahwa modal yang dimiliki oleh calon debitur untuk mengelola suatu usaha minimal $50 \%$ dari biaya pengelolaan usaha tersebut.

3) Capacity (Kemampuan).

Analisa yang dilakukan terhadap kemampuan pengembalian pinjaman nasabah ke BMT Taqwa Muhammadiyah. Hal ini bisa dilihat dari laporan laba rugi usaha calon nasabah.

4) Collateral (Agunan).

Yaitu kemampuan calon debitur dalam memberikan agunan yang baik serta memiliki nilai yang baik. Agunan ini merupakan jaminan tambahan yang diperlukan dalam hal pemberian fasilitas pembiayaan. Agunan berperan penting apabila terjadi wanprestasi dari debitur atau adanya pembiayaan bermasalah, maka BMT Taqwa Muhammdiyah Padang dengan segera dapat mengkonversikannya kepada sejumlah uang yang lebih likuid.

5) Condition of Economic (Kondisi perekonomian).

BMT akan melihat bagaimana jenis usaha nasabah dan mengkaitkannya dengan kondisi ekonomi sekarang dan kemungkinan yang akan terjadi dimasa yang akan datang. Adapun yang menjadi perhatian bagi BMT Taqwa Muhammadiyah Padang adalah kebijakan pemerintah dalam perekonomian 
Usaha Kecil Menengah (UKM), politik, sosial, budaya dan segi lainnya yang dapat mempengaruhi kondisi ekonomi itu sendiri.

e. Tahap Keputusan Pembiayaan.

Setelah dilakukan analisa, maka hasil dari analisa tersebut akan dirapatkan oleh Kepala Pembiayaan dengan Kepala Cabang, untuk memutuskan layak atau tidak layaknya usaha yang akan dibiayai.

Jika hasilnya layak maka akan dikeluarkan Surat Persetujuan Pasilitas Pembiayaan (SP3) kepada calon nasabah. Jika tidak layak, maka calon nasabah akan diberitahukan melalui telephon.

\section{f. Penandatanganan Aqad Pembiayaan.}

Jika calon nasabah sepakat dengan SP3 yang diterbitkan oleh BMT Taqwa Muhammadiyah, maka proses selanjutnya adalah penandatanganan aqad pembiayaan yang juga dihadiri oleh Notaris.

\section{g. Pencairan Dana.}

Setelah penandatanganan akad, maka nasabah telah bisa mengambil dana dari BMT Taqwa Muhammadiyah. adalah:

Adapun kelengkapan administrasi yang harus ada dalam pembiayaan ini

1) Dokumen Pembiayaan.

Dokumen yang diperlukan dalam pembiayaan di BMT Taqwa

Muhammadiyah Padang adalah :

1. Surat pemberitahuan permohonan nasabah disetujui.

2. Akad al-murabahah dengan notaris.

3. Pengikatan jaminan berupa fidusia, gadai dan Surat Kuasa Memegang Hak Tanggungan (SKMHT).

4. Polis asuransi dengan PT. Asuransi Takaful.

a. Asuransi jiwa.

b. Asuransi jaminan.

5. Surat perintah realisasi pembiayaan.

6. Surat tanda terima penyertaan modal.

7. Surat izin penyitaan jaminan jika terjadi tunggakan berturut - turut selama tiga bulan dari nasabah.

2) Jaminan Pembiayaan.

Pembiayaan yang diberikan oleh BMT Taqwa Muhammadiyah Padang mengandung resiko maka dalam pelaksanaannya BMT Taqwa Muhammadiyah Padang harus mensyaratkan adanya jaminan. Jaminan merupakan keyakinan BMT Taqwa Muhammadiyah atas kesanggupan nasabah untuk melunasi pembiayaan sesuai dengan yang diperjanjikan.

Jaminan dari nasabah untuk pembiayaan yang diberikan oleh BMT Taqwa Muhammadiyah Padang harus dinilai terlebih dahulu. Tujuan dari penilaian tersebut adalah untuk mengetahui nilai ekonomis dari jaminan, serta nilai - nilai yuridis dari barang jaminan tersebut. Di samping tujuan pokok di atas yang harus dilihat adalah jenis jaminan dari kepemilikan barangnya. Barang yang dapat dijadikan sebagai jaminan adalah : 
a) Kekayaan dari nasabah itu sendiri, kekayaannya dapat berupa bangunan dalam bentuk Sertifikat Hak Milik, kendaraan bermotor dalam bentuk BPKB.

b) Kekayaan dari pihak ketiga lainnya yang digunakan untuk menjamin pembiayaan yang diperoleh nasabah dari BMT Taqwa Muhammadiyah Padang. Dalam hal ini yang dijadikan jaminannya adalah Sertifikat Hak Milik atau yang sejenis dengan itu dari jaminan yang diserahkan, dan telah dipindahkan penguasaannya kepada nasabah oleh pemiliknya untuk dijadikan jaminan atas pembiayaan yang diberikan kepada nasabah.

3) Asuransi.

Dalam upaya menghindari resiko yang tidak diinginkan, maka BMT Taqwa Muhammadiyah Padang harus hati - hati dalam memberikan pembiayaan, sehingga terlindungi dari kerugian yang diakibatkan kegagalan pembiayaan. Namun ketentuan ini pun bisa membawa kesulitan bagi calon nasabah terutama dari golongan ekonomi lemah yang tidak banyak memiliki aset yang dapat dijadikan sebagai agunan pembiayaan. Untuk itu dalam penanggulangan resiko yang akan terjadi, BMT Taqwa Muhammadiyah Padang mengikutsertakan nasabah pembiayaan dalam program asuransi.

Objek yang akan diasuransikan adalah jiwa nasabah. Pihak BMT Taqwa Muhammadiyah Padang juga mengikutsertakan jaminan yang diberikan nasabah pada program asuransi takaful, kalau ikut serta dalam program asuransi sedangkan jaminan dikhawatirkan akan di landa hal yang tidak di duga yang dapat mengakibatkan nilai jaminan berkurang ataupun habis. Jika pada saat tertentu nasabah pembiayaan tidak dapat melunasi pembiayaan di BMT Taqwa Muhammadiyah Padang, maka akan di beck - up oleh perusahaan asuransi yang mana besar preminya ditanggung oleh nasabah. Contoh dari objek jaminan yang diasuransikan dapat berupa bangunan.

4) Realisasi Pembiayaan.

Sebelum pembiayaan direalisasikan maka ada beberapa syarat yang harus dipenuhi diantaranya :

1) Permohonan pembiayaan nasabah telah disetujui oleh pihak BMT Taqwa Muhammadiyah Padang.

2) Telah membuka rekening tabungan mudharabah dan pembiayaan.

3) Jaminan telah diperiksa dan disetujui sebagai barang jaminan yang akan dipergunakan sebagai pengikatan antara nasabah pembiayaan dengan BMT Taqwa Muhammadiyah Padang.

4) Telah menandatangani surat perjanjian (akad pembiayaan), pengikatan perjanjian diadakan dihadapan notaris.

5) Menandatangani slip realisasi pembiayaan.

\section{KESIMPULAN}

Berdasarkan uraian pada bab-bab sebelumnya, maka dapat diambil kesimpulan sebagai berikut :

1) Sasaran utama kegiatan BMT Taqwa Muhammadiyah Padang adalah pada kegiatan usaha produktif, dengan memadukan fungsi Baitul 
Maal dan Baitul Tamwil. Baitul Maal adalah lembaga yang mengarah pada usaha-usaha pengumpulan dan penyaluran dana yang non profit, yang fungsinya sebagai mediator antara penyaluran zakat, infak dan shadaqoh dengan para mustahik. Baitul Tamwil adalah lembaga komersil yang berfungsi sebagai mediator antara masyarakat yang memiliki kelebihan dana dengan masyarakat yang memiliki kekurangan dana untuk usaha yang produktif.

2) Fungsi dan peranan BMT Taqwa Muhammadiyah adalah sebagai penyedia dan pengelola jasa keuangan. Kegiatan jasa keuangan yang dikembangkan oleh BMT Taqwa Muhammadiyah adalah penghimpunan dana dan menyalurkannya melalui kegiatan pembiayaan dari anggota dan untuk anggota atau non anggota.

3) Produk dan Layanan BMT Taqwa Muhammadiyah Padang terbagi menjadi dua yaitu produk penghimpunan dana dan produk penyaluran dana, produk penghimpunan dana meliputi al-wadiah, al-mudharabah, alamanah, sedangkan produk penyaluran dana terbagi menjadi beberapa sistem yaitu sistem bagi hasil meliputi pembiayaan mudharabah dan pembiayaan musyarakah, sistem jual beli meliputi pembiayaan murabahah, dan bai' bitsaman ajil, sistem non profit meliputi pembiayaan qhardul hasan, sistem akad bersyarikat meliputi al-musyarakah dan al-mudharabah, dan sistem pembiayaan meliputi pembiayaan al-murabahah, pembiayaan al-bai' bistman ajil, pembiayaan al-mudharabah dan pembiayaan almusyarakah.

4) Pembiayaan Murabahah di BMT Taqwa Muhammadiyah Padang menggunakan akad murabahah wal wakalah ( jual beli yang diwakilkan) dimana akad pembelian barangnya diwakilkan ke nasabah untuk membelinya.

5) Pemberian Pembiayaan Murabahah yang dilakukan oleh BMT Taqwa Muhammadiyah Padang sangat membantu masyarakat dalam pembelian barang guna mengembangkan usaha mereka khususnya masyarakat menengah kebawah yang memililiki usaha mikro dan kecil.

6) Prosedur Pemberian Pembiayaan Murabahah BMT Taqwa Muhammadiyah Padang yaitu terlebih dahulu calon nasabah mengisi formulir permohonan pembiayaan, kemudian diperiksa kelengkapan administrasi calon nasabah oleh Administrasi Pembiayaan, setelah itu maka dilakukan survei oleh Kepala Cabang dengan Kepala Pembiayaan atau Kepala Pembiayaan dengan Account Officer, kemudian data - data yang di dapat dari hasil survei di analisa oleh Kepala Pembiayaan, setelah dilakukan analisa maka diambilah keputusan diterima atau ditolaknya permintaan pembiayaan, bila permintaan calon nasabah dianggap layak maka dikeluarkan Surat Persetujuan Pasilitas Pembiayaan (SP3), jika calon nasabah sepakat dengan SP3 maka dilakukan penandatanganan aqad pembiayaan, setelah itu maka nasabah bisa mengambil dana yang dibutuhkan. 


\section{DAFTAR PUSTAKA}

Adiwarman, A. Karim. 2006. Bank Islam; Analisis Fiqih dan Keuangan. Edisi tiga. Jakarta: PT Raja Grafindo Persada.

Alanshari, F., \& Marlius, D. (2018). Prosedur Pemberian Kredit KPR Pada PT. Bank Tabungan Negara (Persero) TBK Cabang Pembantu Bukittinggi. https://doi.org/10.31227/osf.io/rsfhc

Amelia, L., \& Marlius, D. (2018). Pengendalian Kredit Dalam Upaya Menciptakan Bank Yang Sehat Pada PT. Bank Pembangunan Daerah Sumatera Barat Cabang Utama Padang. https://doi.org/10.31227/osf.io/kpc64

Antonio, Muhammad Syafi'i. 1999. Bank Syariah. Jakarta: Tazkia Institute.

Antonio, Muhammad Syafi'i. 2001. Bank Syariah dari Teori ke Praktek., Jakarta: Gema Insani Press.

Albone, Abdul Aziz, dkk 2009. Panduan Penyusunan Proposal Penelitian dengan Mudah. Yayasan Jihabul Khair Center: Padang.

Ascarya. 2007. Akad dan Produk Bank Syari'ah. Jakarta: Raja Garfindo Persada.

Aziz, Amin. 2004. Pedoman Pendirian BMT. Jakarta: Pinbuk Press.

Darmawanto, \& Fernos, J. (2019). Prosedur Pemberian Kredit Pada Bank Nagari Cabang Sijunjung. https://doi.org/10.31227/osf.io/psqfy

Djajuli dan Yadi Janwari. 2002. Lembaga-Lembaga Perekonomian Umat: Sebuah Pengenalan, Jakarta: Raja Grafindo Persada.

Djumhana, 2000. Hukum Perbankan di Indonesia. Bandung: Citra Aditya Bhakti.

Fatwa Dewan Syari'ah Nasional MUI No. 4/DSN-MUI/IV/2000 tentang Murabahah.

Heri, Sudarsono. 2007. Bank dan Lembaga Keuangan Syariah: Deskripsi dan Ilustrasi. Yogyakarta: Ekonosia.

Kasmir. 2002. Bank dan Lembaga Keuangan Lainnya. Jakarta: PT RajaGrafindo Persada.

Muhammad. 2005. Manajemen Pembiayaan Bank Syari'ah. Yogyakarta: Akademi Manajemen Perusahaan YKPN. 
Pinbuk, 2008. SOM dan SOP Panduan Operasioanal Manajemen Prosedur. Jakarta: Pinbuk Press.

Poerwadarminta, W.J.S . 1991. Kamus Umum Bahasa Indonesia. Jakarta: Balai Pustaka.

Ridwan, M. 2004. Manajemen Baitul Maal Wa Tamwill. Yogyakarta: UII press.

Rodoni, Ahmad. 2008. Lembaga Keuangan Syariah. Jakarta: Dzikrul Hakim.

Syafi'I Antonio, Muhammad. 2001. Bank Syariah Dari Teori Ke Praktik. Jakarta: Gema Insani.

Suhendi, Hendi. 2004. BMT Bank Islam: Instrument Lembaga Keuangan Syariah. Bandung: Putaka Bani Quraisy.

Suhendi, Hendi. 2008. Fiqih Muammalah. Jakarta: PT. Raja Grafindo Persada.

Sumitro, Warkum. 1996. Azas-Azas Perbankan Islam dan Lembaga-Lembaga Terkait. Jakarta: PT.Grafindo Persada.

Widayati, R. (2019). Pelaksanaan Prinsip Kehati-Hatian Dalam Pemberian Kredit Konsumtif Pada Bank Nagari Cabang Siteba. https://doi.org/10.17605/OSF.IO/FZVXR

Widayati, R. (2019). Aktivitas Pemberian Kredit Komersil Pada Bank Nagari Cabang Sijunjung. https://doi.org/10.17605/OSF.IO/QTVZ9

Widayati, R. (2019). Pelaksanaan Kredit Pada Bank Perkreditan Rakyat LPN Pasar Baru Durian Sawahlunto. https://doi.org/10.17605/OSF.IO/5HPAB

Widayati, R. (2019). Aktivitas Pemberian Kredit Usaha Pada PT. Bank Perkreditan Rakyat Batang Kapas. https://doi.org/10.17605/OSF.IO/EDPN4

Wiroso. 2005. Jual Beli Murabahah. Yogyakarta: UII Press. 